\title{
Sindrom pekućih usta - što je novo u terapijskom pristupu?
}

\section{Burning mouth syndrome - what is new therapeutic approach?}

\author{
Bernarda Mrak ${ }^{1}$, Miranda Muhvić Urek², Sonja Pezelj-Ribarić2,3, Vanessa Zuber ${ }^{2}$, Irena Glažar ${ }^{2 *}$
}

\begin{abstract}
Sažetak. Sindrom pekućih usta predstavlja kompleksan poremećaj kroničnog bola multifaktorijalnoga podrijetla. Sindrom predstavlja izazov u dijagnostici tijekom kliničkog rada. Najveća zastupljenost uočena je u ženskoj populaciji. Prosječna pojavnost kod žena u odnosu na muškarce iznosi 7 : 1. Razvoj sindroma povezuje se s lokalnim, sustavnim, psihološkim i neurološkim poremećajima. Uz pečenje oralne sluznice koje obuhvaća najčešće prednje dvije trećine jezika, pacijenti se javljaju i sa simptomima promjene okusa i suhoće usta. Današnji terapijski pristup obuhvaća medikamentoznu terapiju, kao i bihevioralne i alternativne metode. Svrha ovog rada je prikazati sindrom pekućih usta s osvrtom na terapijski pristup predstavljen u recentnoj literaturi.
\end{abstract}

Ključne riječi: lijekovi; sindrom pekućih usta; terapija

Abstract. Burning mouth syndrome is a complex chronic pain disorder of multifactorial origin. The syndrome presents a challenge during clinical work. The highest prevalence was observed in the female population. The average incidence between male and female is 7:1. The development of the syndrome is associated with local, systemic, psychological and neurological causes. Burning sensations usually spans the first two thirds of the tongue. Patients usualy have taste distuurbance and dry mouth sensation. Today's therapeutic approach includes medication therapy as well as behavioral and alternative methods. The purpose of this paper is to present burning mouth syndrome with a review of the therapeutic approach presented in the recent literature.

Key words: burning mouth syndrome; drugs; therapy
${ }^{1}$ Dom zdravlja Primorsko-goranske županije, Ordinacija dentalne medicine, Rijeka, Hrvatska

${ }^{2}$ Katedra za oralnu medicinu i parodontologiju, Fakultet dentalne medicine Sveučilišta u Rijeci, Rijeka, Hrvatska

${ }^{3}$ Fakultet za dentalnu medicinu i zdravstvo Sveučilišta u Osijeku, Osijek, Hrvatska
*Dopisni autor:

Izv. prof. dr. Irena Glažar, dr. med. dent. Katedra za oralnu medicinu i parodontologiju, Fakultet dentalne medicine Sveučilišta u Rijeci

Krešimirova 40/42, 51000 Rijeka, Hrvatska E-mail: irena.glazar@fdmri.uniri.hr

http://hrcak.srce.hr/medicina 


\section{UVOD}

Sindrom pekućih usta (SPU) opisuje se prvi put 1935. godine. Izostanak jasnih kliničkih znakova kod pacijenata sa SPU-om otežava postavljanje dijagnoze i terapijski pristup ${ }^{1,2}$. International Health Society (IHS) 2004. godine prvi definira primarni SPU kao „intraoralnu pekuću senzaciju nepoznatog etiološkog uzroka“" ${ }^{\text {. }}$ U literaturi se sindrom može naći pod različitim nazivima, kao što su stomatodinija, stomatopiroza, glosopiroza,

Sindrom pekućih usta predstavlja kompleksan poremećaj kroničnog bola multifaktorijalnoga podrijetla. Razvoj sindroma pekućih usta povezuje se s lokalnim, sustavnim, psihološkim i neurološkim poremećajima.

glosodinija, bolna usta, bolan jezik i oralna dizestezija. lako je za opis sindroma ovakva podjela stvorila vjerojatno veću konfuziju, takva klasifikacija ima smisla ako se želi naglasiti lokalizacija i jačina bola ${ }^{2,3}$. Scala i suradnici ${ }^{4}$ navode da bol koji se ne može povezati bilo kakvim lokalnim ili sustavnim uzročnikom naziva „pravi“ SPU. Najvažniji razlog koji otežava postavljanje dijagnoze i provođenje terapije je nedostatak saznanja patofizioloških mehanizama ovog sindroma ${ }^{5}$. Vrh i prednje dvije trećine jezika najčešće su zahvaćeni, ali učestala je pojava bilateralnog i simetričnog bola može zahvatiti sva područja oralne sluznice ${ }^{2,4}$. Mogući etiološki uzročnici sindroma podijeljeni su na lokalne, sustavne, psihološke, neurološke i idiopatske čimbenike ${ }^{3}$. Među lokalne čimbenike navode se parafunkcijske navike, mehaničke i kemijske iritacije, alergijske reakcije, hiposalivacija, oralne (bakterijske, virusne ili gljivične) infekcije te promjene na oralnoj sluznici, kao što su migrirajući glositis, fisuriran jezik i lihen planus ${ }^{1,6}$. Sustavni čimbenici mogu biti povezani sa smanjenom razinom vitamina $B 1, B 2$, B6, B12, folata, željeza, cinka, nepravilnim radom štitnjače, hormonalnim promjenama, autoimunim bolestima (dijabetes, Sjorgen sindrom), gastrointestinalnim bolestima, upotrebom lijekova (kemoterapeutici, antibiotici, antihistaminici, antiretroviralni, benzodijazepini) ${ }^{2,3,6,7}$. Grushka i suradnici $^{8}$ u svom istraživanju na 102 ispitanika sa
SPU-om ne navode značajnu razliku ispitivane i kontrolne skupine $u$ pojavnosti oralnom nalazu, kandidijalne infekcije te hematoloških i nutritivnih poremećaja. lako se zbog male skupine ispitanika ne može dobiti generalna slika sindroma, jedini je značajno promijenjen nalaz razine sedimentacije eritrocita što govori u prilog prisutnosti upale u organizmu. Nedostatak organskih faktora kod pacijenata sa SPU-om često se povezuje $s$ psihogenim stanjima koja imaju značajan utjecaj na svakodnevni život pojedinca. Depresija, anksioznost i kancerofobija opisane su kao učestalije dijagnoze kod SPU-a ${ }^{4,6,9,10}$. lako uzročno-posljedična veza između psiholoških poremećaja i SPU-a nije pronađena, depresija, anksioznost, kancerofobija, opsesivno-kompulzivni poremećaj i psihosocijalne stresne traumatske situacije opisuju se kao psihološki čimbenici koji mogu biti potičući čimbenik u nastanku SPU-a ${ }^{11}$. Dobro uzeta anamneza uz temeljit klinički pregled i dodatne dijagnostičke i laboratorijske pretrage pomoći će postavljanju dijagnoze ovog kompleksnog sindro$\mathrm{ma}^{12}$.

\section{KRITERIJ PRETRAŽIVANJA}

Prilikom pretraživanja literature korištena je MEDLINE baza. Kako bi se suzila pretraga na radove objavljene posljednjih pet godina, koristila se Mesh PubMed Database predmetnica te je pomoću Booleovog operatera upisano: „Burning Mouth Syndrome“ AND „therapy“ OR „therapeutics". Pretraga je ograničena samo na radove s kliničkim ispitivanjima na engleskom jeziku. Od početnog stanja dobiveno je 20 filtriranih radova prikazanih u tablici 1 .

\section{EPIDEMIOLOGIJA}

Sindrom je prisutan od $0,7 \%$ do $15 \%$ unutar populacije, a pojavnost se povećava s godinama. Različite stope zastupljenosti u populaciji prisutne su zbog razlika $u$ ispitivanju grupa te zbog nedostataka jedinstvenog dijagnostičkog kriterija koji bi potvrdio prisutnost sindroma. SPU se može javiti kod osoba između 27 i 87 godina². Najveća zastupljenost uočena je kod žena u dobi između $60-69$ godina $^{12,13}$. U dobnoj skupini ispod 30 godina sindrom je izuzetno rijedak te nije zabilježena pojavnost u adolescentnoj i dječjoj dobi. 
Tablica 1. Terapijski pristup sindromu pekućih usta

\begin{tabular}{|c|c|c|c|c|}
\hline STUDIJA/GODINA & ISPITANICI & CILJ & TERAPIJA & ZAKLJUČCI/REZULTATI \\
\hline $\begin{array}{l}\text { Melatonin Treatment in } \\
\text { Patients with Burning } \\
\text { Mouth Syndrome: A } \\
\text { Triple-Blind, Placebo- } \\
\text { Controlled, Crossover } \\
\text { Randomized Clinical Trial } \\
/ 2018^{33}\end{array}$ & $\begin{array}{l}20 \text { pacijenata sa } \\
\text { SPU-om ( } 35 \text { do } 82 \\
\text { godina) }\end{array}$ & $\begin{array}{l}\text { Ispitati učinkovitost melatonina } \\
\text { i placebo lijeka u smanjenju } \\
\text { bola kod SPU-a, neželjena } \\
\text { svojstva te djelovanje na } \\
\text { kvalitetu sna, stupanj } \\
\text { anksioznosti i razinu serumskog } \\
\text { i salivarong melanina. }\end{array}$ & $\begin{array}{l}12 \mathrm{mg} / \text { dnevno tijekom } 8 \\
\text { tjedana }\end{array}$ & $\begin{array}{l}\text { Melatonin se nije pokazao } \\
\text { značajnim sredstvom u } \\
\text { ublažavanju bola. }\end{array}$ \\
\hline $\begin{array}{l}\text { Evaluation of laser therapy } \\
\text { and alpha-lipoic acid for } \\
\text { the treatment of burning } \\
\text { mouth syndrome: a } \\
\text { randomized clinical trial/ } \\
2018^{34}\end{array}$ & $\begin{array}{l}44 \text { pacijenta } \\
\text { podijeljena u } 4 \\
\text { skupine i } 8 \text { pacijenata } \\
\text { u kontrolnoj skupini }\end{array}$ & $\begin{array}{l}\text { Izmjeriti učinkovitost alfa } \\
\text { lipoične kiseline (ALK) i terapije } \\
\text { laserom niske snage (LLLT) od } \\
\text { pacijenata sa SPU-om i } \\
\text { sekundarnim oralnim bolom } \\
\text { (SOB). }\end{array}$ & $\begin{array}{l}\text { BMS/laser }(n=10), \text { BMS/ } \\
\text { ALA }(n=5), \text { SOB/laser } \\
(n=15) \text { i SOB/ALA }(n=14)\end{array}$ & $\begin{array}{l}\text { ALK I LLLT pokazali su se } \\
\text { učinkoviti u smanjenju } \\
\text { simptoma pečenja. }\end{array}$ \\
\hline $\begin{array}{l}\text { Analgesic effect of topical } \\
\text { oral capsaicin gel in } \\
\text { burning mouth syndrome } \\
/ 2017^{35}\end{array}$ & $\begin{array}{l}22 \text { ispitanice sa } \\
\text { SPU-om }\end{array}$ & $\begin{array}{l}\text { Istražiti učinkovitost dviju } \\
\text { različitih koncentracija capsaicin } \\
\text { gela. }\end{array}$ & $\begin{array}{l}\text { Aplikacija } 0.01 \% \text { ili } \\
0.025 \% \text { gela na dorzalnu } \\
\text { stranu jezika } 3 \times \text { dnevno } \\
\text { tijekom } 14 \text { dana. }\end{array}$ & $\begin{array}{l}\text { Korištenje gela pokazalo je } \\
\text { kratkotrajna poboljšanja, ali } \\
\text { značajna statistička učinkovitost } \\
\text { obiju koncentracija nije nađena. }\end{array}$ \\
\hline $\begin{array}{l}\text { Effects of low-level laser } \\
\text { therapy on burning mouth } \\
\text { syndrome/ } 2017^{36}\end{array}$ & $\begin{array}{l}44 \text { pacijenta } \\
\text { podijeljena u } 3 \text { grupe }\end{array}$ & $\begin{array}{l}\text { Ispitati učinkovitost LLLT-a } \\
\text { (GaAIAs lasera) kod SPU-a } \\
\text { tijekom tri tjedna. }\end{array}$ & $\begin{array}{l}\text { Grupa } 1 . \text { (16 ispitanika) } \\
815 \mathrm{~nm} \text { valne dužine } 1 \mathrm{~W}, \\
\text { 4J, kontinuirane emisije od } \\
\text { 4s, } 133.3 \mathrm{~J} / \mathrm{cm}^{2} \text {. } \\
\text { Grupa } 2 . \text { (16 ispitanika) } \\
815 \mathrm{~nm}, 1 \mathrm{~W} \text {, emisija od } 6 \\
\mathrm{~s}, 6 \mathrm{~J} \text { i } 200 \mathrm{~J} / \mathrm{cm}^{2} \text {. } \\
\text { Grupa } 3 \text { ( } \mathrm{n}=12 \text { ) placebo } \\
\text { grupa, sham laser. }\end{array}$ & $\begin{array}{l}\text { Grupa } 1 \text { i } 2 \text { za razliku od placebo } \\
\text { grupe bilježe značajno } \\
\text { smanjenje simptoma od } \\
\text { početka do kraja terapije. }\end{array}$ \\
\hline $\begin{array}{l}\text { Low Intensity laser } \\
\text { therapy in patients with } \\
\text { burning mouth syndrome } \\
\text { a randomized, placebo- } \\
\text { controlled study } / 2016^{37}\end{array}$ & $\begin{array}{l}13 \text { pacijenata u } \\
\text { glavnoj i } 10 \text { u placebo } \\
\text { skupini }\end{array}$ & $\begin{array}{l}\text { Ispitati učinkovitost LLLT-a kod } \\
\text { pacijenata sa SPU-om. }\end{array}$ & $\begin{array}{l}\text { Svaki je pacijent primio } 4 \\
\text { zračenja } 2 \text { x tjedno kroz } \\
\text { dva uzastopna tjedna. } \\
\text { Korišten je AsGaAl laser } \\
790 \mathrm{~nm}, 20 \mathrm{~m}, 6 \mathrm{~J} / \mathrm{cm}^{2} .\end{array}$ & $\begin{array}{l}\text { Zamijećena je značajna razlika } \\
\text { prilikom upotrebe lasera } 90 \\
\text { dana od posljednjeg zračenja } 6 \\
\text { od } 13 \text { pacijenata pokazuje } \\
\text { potpunu remisiju simptoma, } \\
\text { dok placebo grupa bilježi } \\
\text { rezultat kod } 4 \text { od } 10 \text { pacijenata. }\end{array}$ \\
\hline $\begin{array}{l}\text { Combined Acupuncture } \\
\text { and Auriculotherapy in } \\
\text { Burning Mouth Syndrome } \\
\text { Treatment: A Preliminary } \\
\text { Single-Arm Clinical } \\
\text { Trial/ } 2017^{38}\end{array}$ & $\begin{array}{l}8 \text { pacijenata sa } \\
\text { SPU-om }\end{array}$ & $\begin{array}{l}\text { Ispitati učinak kombinirane } \\
\text { terapije akupunkture i } \\
\text { aurikuloterapije na smanjenje } \\
\text { bola i poboljšanje kvalitete } \\
\text { života kod pacijenata sa } \\
\text { SPU-om. }\end{array}$ & $\begin{array}{l}\text { U } 11 \text { tretmana tijekom } 6 \\
\text { tjedana ispitanicima su se } \\
\text { kombinirale metode } \\
\text { akupunkture i } \\
\text { aurikuloterapije. }\end{array}$ & $\begin{array}{l}\text { Kombinirana terapija pokazala } \\
\text { se učinkovitom u smanjenju } \\
\text { simptoma pečenja i poboljšanju } \\
\text { kvalitete života tijekom } \\
\text { dvogodišnjeg praćenja. }\end{array}$ \\
\hline $\begin{array}{l}\text { Spatial and Temporal Brain } \\
\text { Responses to Noxious } \\
\text { Heat Thermal Stimuli in } \\
\text { Burning Mouth } \\
\text { Syndrome } / 2016^{39}\end{array}$ & $\begin{array}{l}16 \text { desnorukih žena s } \\
\text { dijagnozom } \\
\text { primarnog SPU-a i } 15 \\
\text { zdravih ispitanica u } \\
\text { kontrolnoj skupini }\end{array}$ & $\begin{array}{l}\text { Usporedba moždanog odgovora } \\
\text { na stimulanse topline kako bi se } \\
\text { dokazao specifični moždani } \\
\text { odgovor nastao zbog oštećene } \\
\text { funkcije centralnog i perifernog } \\
\text { živčanog sustava kod SPU-a. }\end{array}$ & $\begin{array}{l}\text { Termalne sekvence od } 32 \\
{ }^{\circ} \mathrm{C} \text { do } 40{ }^{\circ} \mathrm{C} \text { te od } 32{ }^{\circ} \mathrm{C} \text { do } \\
49{ }^{\circ} \mathrm{C} \text { ponavljale su se na } \\
\text { području lijevog dlana i } \\
\text { donje usne po } 32 \text { sekunde. }\end{array}$ & $\begin{array}{l}\text { Pomoću MR-a otkrilo se kako je } \\
\text { odgovor parahipokampalne } \\
\text { regije različito percipiran kod } \\
\text { SPU skupine te kako postoji } \\
\text { povezanost između primljenog } \\
\text { bola i supresije moždane } \\
\text { aktivnosti u prednjem djelu } \\
\text { cingularnog korteksa zbog } \\
\text { ponovljene termalne sekvence } \\
\text { na području donje usne. }\end{array}$ \\
\hline $\begin{array}{l}\text { A randomized pilot study } \\
\text { to assess the safety and } \\
\text { the value of low-level laser } \\
\text { therapy versus } \\
\text { clonazepam in patients } \\
\text { with burning mouth } \\
\text { syndrome } / 2016^{30}\end{array}$ & $\begin{array}{l}18 \text { pacijenata u } \\
\text { laserskoj grupi i } 15 \\
\text { pacijenata na terapiji } \\
\text { klornazepamom }\end{array}$ & $\begin{array}{l}\text { Ispitati učinkovitost i razliku } \\
\text { klornazepama i LLLT-a. }\end{array}$ & $\begin{array}{l}\text { Grupa1 : } 2 \text { x tjedno } \\
\text { zračenje tijekom } 5 \text { tjedana } \\
\text { AlGaAS } 300 \mathrm{~mW}, 10 \mathrm{~J} / \mathrm{cm}^{2} \text {, } \\
1 \mathrm{~W} \\
\text { Grupa 2: tabletu } \\
\text { klornazepama pacijenti su } \\
\text { držali } 3 \text { minute na bolnom } \\
\text { mjestu bez ingesije. } \\
1 \mathrm{mg} / 3 \mathrm{x} \text { dnevno / } 21 \text { dan. }\end{array}$ & $\begin{array}{l}\text { Terapija laserom pokazala je } \\
\text { značajno smanjenje bola nakon } \\
12 \text { tjedana od završetka } \\
\text { terapije. Klornazepam nije } \\
\text { pokazao značajnu razliku u } \\
\text { odnosu na prvu skupinu. Razina } \\
\text { anksioznosti i depresije u obje } \\
\text { skupine nije se promijenila. }\end{array}$ \\
\hline
\end{tabular}




\begin{tabular}{|c|c|c|c|c|}
\hline STUDIJA/GODINA & ISPITANICI & CILJ & TERAPIJA & ZAKLJUČCI/REZULTATI \\
\hline $\begin{array}{l}\text { Effect of a } 2 \% \text { topical } \\
\text { chamomile application for } \\
\text { treating burning mouth } \\
\text { syndrome: a controlled } \\
\text { clinical trial } / 2016^{40}\end{array}$ & $\begin{array}{l}57 \text { pacijenata } \\
\text { podijeljenih u } 2 \text { grupe }\end{array}$ & $\begin{array}{l}\text { Ispitati djelovanje } 2 \% \text { gela } \\
\text { kamilice na smanjenje bola, } \\
\text { kserostomije i poboljšanja } \\
\text { kvalitete života. }\end{array}$ & $\begin{array}{l}2 \text { puta dnevno tijekom } \\
\text { mjesec dana. Grupa } 1 \\
\text { primala je topikalni } \\
\text { pripravak } 2 \% \text { gela kamilice, } \\
\text { dok je druga grupa dobivala } \\
\text { placebo pripravak. }\end{array}$ & $\begin{array}{l}\text { Terapeutski pripravak } 2 \% \text { gela } \\
\text { kamilice nije pokazao značajan } \\
\text { učinak između dvije ispitane } \\
\text { skupine. }\end{array}$ \\
\hline $\begin{array}{l}\text { The Efficacy of Daily } \\
\text { Prefrontal Repetitive } \\
\text { Transcranial Magnetic } \\
\text { Stimulation (rTMS) for } \\
\text { Burning Mouth Syndrome } \\
\text { (BMS): A Randomized } \\
\text { Controlled Single-blind } \\
\text { Study/2016 }\end{array}$ & $\begin{array}{l}20 \text { pacijenata sa } \\
\text { SPU-om podijeljenih } \\
\text { u dvije skupine }\end{array}$ & $\begin{array}{l}\text { Dokazati učinkovitost } \\
\text { ponavljajuće transkranijalne } \\
\text { magnetske stimulacije na } \\
\text { smanjenje bola kod SPU-a. }\end{array}$ & $\begin{array}{l}\text { Od ukupno } 30000 \text { pulseva } \\
\text { koje su primile obje grupe, } \\
\text { grupa } 1(\mathrm{n}=12 \text { ) imala je } \\
\text { postavku (TMS) na } 110 \mathrm{~Hz} \text { i } \\
\text { druga (placebo) grupa ( } \mathrm{n}= \\
\text { 8) primala je sham laser. }\end{array}$ & $\begin{array}{l}\text { U prvoj skupini zabilježeno je } \\
\text { značajno smanjenje bola nakon } \\
\text { tjedan dana terapije s obzirom } \\
\text { na kontrolnu skupinu. }\end{array}$ \\
\hline $\begin{array}{l}\text { Effect of a local anesthetic } \\
\text { lozenge in relief of } \\
\text { symptoms in burning } \\
\text { mouth syndrome } / 2016^{32}\end{array}$ & $\begin{array}{l}18 \text { pacijenata } \\
\text { podijeljenih u } 2 \\
\text { skupine pacijenata }\end{array}$ & $\begin{array}{l}\text { Ispitati učinkovitost bupivakaina } \\
\text { na simptome bola, okusne } \\
\text { alteracije i kserostomije kod } \\
\text { pacijenata sa SPU-om. }\end{array}$ & $\begin{array}{l}\text { Pastile bupivakaina i } \\
\text { placebo tablete; } 3 \mathrm{x} \\
\text { dnevno tijekom } 2 \text { tjedna }\end{array}$ & $\begin{array}{l}\text { Rezultati su pokazali statističku } \\
\text { značajnu razliku ali klinički } \\
\text { minimalnu u smanjenju bola } \\
\text { prilikom korištenja bupivakaina. } \\
\text { Utjecaj na kserostomiju nije bio } \\
\text { opažen. }\end{array}$ \\
\hline $\begin{array}{l}\text { Efficacy of low-level laser } \\
\text { therapy for the treatment } \\
\text { of burning mouth } \\
\text { syndrome: a randomized, } \\
\text { controlled trial./2015 } 29\end{array}$ & $\begin{array}{l}78 \text { ispitanika } \\
\text { podijeljenih u } 4 \\
\text { skupine }\end{array}$ & $\begin{array}{l}\text { Ispitati učinak LLLT-a kod } \\
\text { pacijenata sa SPU-om. }\end{array}$ & $\begin{array}{l}\text { 1. grupa: infracrveni laser: } \\
\text { IR1W, } \mathrm{n}=20 \text { ( } 830 \mathrm{~nm}, 100 \\
\mathrm{~mW}, 5 \mathrm{~J}, 176 \mathrm{~J} / \mathrm{cm} 2,50 \mathrm{~s}, \\
\text { LLLT } 1 \times \text { tjedno tijekom } 10 \\
\text { tjedana); } \\
\text { grupa 2. IR3W, } \mathrm{n}=20 \text { ( } 830 \\
\mathrm{~nm}, 100 \mathrm{~mW}, 5 \mathrm{~J}, 176 \\
\mathrm{~J} / \mathrm{cm} 2,50 \mathrm{~s}, 3 \times \text { tjedno } 3 \\
\text { tjedna; } 3 . \text { grupa crveni } \\
\text { laser InGaAIP } \mathrm{n}=19 \text { ( } 685 \\
\mathrm{~nm}, 35 \mathrm{~mW}, 2 \mathrm{~J}, 72 \mathrm{~J} / \mathrm{cm} 2 \text {, } \\
58 \mathrm{~s},) 3 \times \text { tjedno } 3 \text { tjedna; } \\
\text { 4. grupa (kontrolna) sham } \\
\text { laser } \mathrm{n}=19\end{array}$ & $\begin{array}{l}\text { Prva i druga ispitivana skupina } \\
\text { pokazuju značajne rezultate u } \\
\text { ispitivanim parametrima. Nema } \\
\text { značajne razlike između } \\
\text { kontrolne skupine i treće } \\
\text { skupine. }\end{array}$ \\
\hline $\begin{array}{l}\text { Phototherapy on the } \\
\text { Treatment of Burning } \\
\text { Mouth Syndrome: A } \\
\text { Prospective Analysis of } 20 \\
\text { Cases } / 2015^{42}\end{array}$ & $\begin{array}{l}20 \text { pacijenata sa } \\
\text { SPU-om }\end{array}$ & Učinak laserske terapije na SPU. & $\begin{array}{l}\text { Laserska fototerapija } 660 \\
\mathrm{~nm} / 10 \text { tjedana, } 40 \mathrm{~mW}, 10 \\
\text { J i 0,4 J po točki, dužina } \\
\text { iradijacije } 10 \mathrm{~s}\end{array}$ & $\begin{array}{l}\text { Kod } 49 \text { \% pacijenata došlo je do } \\
\text { poboljšanja simptoma. }\end{array}$ \\
\hline $\begin{array}{l}\text { Alpha lipoic acid efficacy in } \\
\text { burning mouth syndrome. } \\
\text { A controlled clinical } \\
\text { trial } / 2015^{43}\end{array}$ & $\begin{array}{l}60 \text { pacijenata sa } \\
\text { SPU-om podijeljenih } \\
\text { u dvije grupe }\end{array}$ & $\begin{array}{l}\text { Istražiti učinkovitost alfa lipoične } \\
\text { kiseline i odrediti statističku } \\
\text { značajnost istraživanih varijabli. }\end{array}$ & $\begin{array}{l}\text { Prva grupa pacijenata } \\
\text { primala je } 600 \mathrm{mg} / \text { dnevno } \\
\text { pripravka (svakih } 8 \text { sati } 3 \\
\text { kapsule po } 200 \mathrm{mg} \\
\text { tijekom } 2 \text { mjeseca), dok je } \\
\text { kontrolna primala } \\
\text { placebo. }\end{array}$ & $\begin{array}{l}\text { Kod pacijenata u prvoj skupini } \\
\text { zabilježeno je u } 64 \% \\
\text { poboljšanje simptoma koje je } \\
\text { potrajalo do mjesec dana nakon } \\
\text { terapije. Placebo grupa u } 27,6 \% \\
\text { pokazuje poboljšanje simptoma. }\end{array}$ \\
\hline $\begin{array}{l}\text { The effectiveness of } \\
\text { acupuncture versus } \\
\text { clonazepam in patients } \\
\text { with burning mouth } \\
\text { syndrome/ } 2015^{24}\end{array}$ & $\begin{array}{l}42 \text { pacijenta unutar } \\
\text { dviju skupina }\end{array}$ & $\begin{array}{l}\text { Ispitati učinkovitost i razliku } \\
\text { klonazepama i akupunkture. }\end{array}$ & $\begin{array}{l}\text { Akupunktura je izvršena } \\
\text { na } 20 \text { ispitanika kroz } 4 \\
\text { tjedna ( } 3 \text { puta na tjedan) } \\
\text { na točkama } \\
\text { ST8,GB2,TE21,SI19, SI18 i } \\
\text { LI4 bilateralno kao i na } \\
\text { GV20 centralno. } 22 \\
\text { pacijenta iz druge skupine } \\
\text { je uzimalo klonazepam } 2 \\
\text { tjedna po 0,5 mg jednom } \\
\text { dnevno, ostala } 2 \text { tjedna } \\
\text { 0,5 mg ujutro i navečer. }\end{array}$ & $\begin{array}{l}\text { Obje metode pokazale su slične } \\
\text { rezultate u učinkovitosti. }\end{array}$ \\
\hline $\begin{array}{l}\text { The effect of clonazepam } \\
\text { mouthwash on the } \\
\text { symptomatology of } \\
\text { burning mouth syndrome: } \\
\text { An open pilot study } \\
/ 2014^{44}\end{array}$ & $\begin{array}{l}18 \text { pacijenata, nema } \\
\text { kontrolne grupe }\end{array}$ & $\begin{array}{l}\text { Utjecaj otopine klornazepama } \\
\text { na SPU. }\end{array}$ & $\begin{array}{l}3 \mathrm{x} \text { dnevno tijekom } 14 \\
\text { dana ispitanici uzimaju } \\
\text { otopinu } 10 \mathrm{~mL} \\
\text { klornazepama, koju } \\
\text { mućkaju bez ingestije } 3 \\
\text { minute. }\end{array}$ & $\begin{array}{l}\text { Kod } 66,7 \% \text { pacijenata (12) } \\
\text { zamijećeno je poboljšanje } \\
\text { simptoma opisano kao blaga do } \\
\text { potpuna remisija. Kod ostalih } \\
33 \% \text { pacijenata stanje ostaje } \\
\text { nepromijenjeno. }\end{array}$ \\
\hline
\end{tabular}




\begin{tabular}{|c|c|c|c|c|}
\hline STUDIJA/GODINA & ISPITANICI & CILJ & TERAPIJA & ZAKLUČCI/REZULTATI \\
\hline $\begin{array}{l}\text { Efficacy of lycopene- } \\
\text { enriched virgin olive oil for } \\
\text { treating burning mouth } \\
\text { syndrome: A double-blind } \\
\text { randomised/ } 2014^{45}\end{array}$ & $\begin{array}{l}60 \text { pacijenata sa } \\
\text { SPU-om, podijeljenih } \\
\text { u } 2 \text { skupine }\end{array}$ & $\begin{array}{l}\text { Ispitati učinak maslinovog ulja } \\
\text { bogatog likopenom kod } \\
\text { pacijenata sa SPU-om. }\end{array}$ & $\begin{array}{l}\text { Prva skupina uzimala je } \\
\text { terapiju s djevičanskim } \\
\text { maslinovim uljem bogatim } \\
\text { likopenom ( } 300 \text { ppm,1,5 } \\
\mathrm{mL} 3 \times \text { dnevno) i druga } \\
\text { grupa placebo ulje } 1,5 \mathrm{~mL} \\
3 \times \text { dnevno. Mjerenje je } \\
\text { vršeno prije i } 12 \text { tjedana } \\
\text { od upotrebe ulja. }\end{array}$ & $\begin{array}{l}\text { VAS skala bola pokazala je } \\
\text { poboljšanje u obje grupe ali bez } \\
\text { statističke značajne razlike } \\
(p=0,57) \text {. Nađeno je kako se } \\
\text { tijekom } 3 \text { mjeseca zbog } \\
\text { korištenja maslinovog ulja } \\
\text { bogatog likopenom lipidni profil } \\
\text { nije promijenio. }\end{array}$ \\
\hline $\begin{array}{l}\text { The role of xerostomia in } \\
\text { burning mouth syndrome: } \\
\text { a case-control study/ } \\
2014^{46}\end{array}$ & $\begin{array}{l}38 \text { pacijenata sa } \\
\text { SPU-om }\end{array}$ & $\begin{array}{l}\text { Ispitati učinkovitost topikalnog } \\
\text { pripravka } 10 \% \text { ureje kod } \\
\text { pacijenata sa SPU-om. }\end{array}$ & $\begin{array}{l}3 \text { - } 4 \text { puta dnevno u tri } \\
\text { mjeseca glavnoj grupi } \\
\text { dana je otopina } 10 \% \\
\text { ureje dok je placebo grupa } \\
\text { dobila mješavinu } 5 \% \\
\text { otopine karboksimetilce- } \\
\text { luloze, } 0,15 \% \text { metilparabe- } \\
\text { na i } 10 \% \text { glicerola u } \\
\text { destiliranoj vodi. }\end{array}$ & $\begin{array}{l}\text { Nisu pronađene razlike u } \\
\text { salivarnom protoku, kao ni } \\
\text { okusna, mirisna ili senzorna } \\
\text { promjena. } 60 \% \text { pacijenata } \\
\text { zabilježilo je poboljšanje u oba } \\
\text { pristupa. }\end{array}$ \\
\hline
\end{tabular}

Kada se promatra pojavnost bolesti po spolu, značajno je veći broj oboljelih žena u odnosu na muškarce. Prvi simptomi kod žena javljaju se tri godine prije ili dvanaest godina nakon klimakterija, a to se povezuje s hormonalnom neuravnoteženošću u razdoblju peri- i postmenopauze². Kao neki od razloga izrazite zastupljenosti sindroma $u$ ženskoj populaciji uz hormonalne promjene navode se i sociokulturološki i psihološki čimbenici. $U$ literaturi se navode različiti omjeri od $3: 1$ do 33 : 1 . Ako se isključe žene u razdoblju menopauze, kod kojih incidencija dominira, istraživanja su pokazala kako se promjene u centralnom i perifernom živčanom sustavu javljaju češće kod pacijenata ${ }^{8,14}$. Ostali čimbenici s kojima se povezuje nastanak bolesti su nezaposlene osobe, niže educirane osobe, pacijenti s dijagnozom Parkinsonove bolesti, depresije i anksioznosti te kronična stanja i bolesti kao urogenitalne i/ili gastorintestinalne bolesti2,15

\section{DIJAGNOZA}

Da bi se postavila dijagnoza SPU-a potrebno je potvrditi prisutnost bilateralnog intraoralnog pečenja sluznice koje traje više od četiri mjeseca. Simptomi koje opisuju pacijenti su bol kontinuiranog intenziteta ili intenziteta bola koji se pojačava tijekom dana, izostanak tijekom sna te moguća poboljšanja tijekom konzumacije jela ili pića $2,7,11,13,14$. IHS navodi kako se sindrom može dijagnosticirati ako su pekuće intraoralne senzacije prisutne svakodnevno, minimalno dva sata, više od tri mjeseca bez vidljivog kliničkog prisutnog nalaza jasnih uzročnih lezija ${ }^{1,16,17}$. SPU je definiran kao skup simptoma koji mogu potencijalno doći do izražaja kroz mnoge lokalne i sustavne čimbenike, od kojih neki mogu biti učinkovito eliminirani, a drugi mogu onemogućiti jasniju dijagnozu? Upravo to je velik izazov u postavljanju konačne dijagnoze. Najopsežniji i sadržajan pristup podjele pacijenata predstavili su Lamey i Lewis ${ }^{14}$. Oni su pacijente ovisno o vremenu pojavljivanja simptoma i kvalitete bola podijelili u tri kategorije. U prvoj skupini sadržani su pacijenti kod kojih se pečenje sluznice ne javlja ujutro, ali se pojačava tijekom dana s razvojem najjačeg intenziteta u večernjim satima. Druga skupina pacijenata ima kontinuirane senzorne smetnje tijekom dana, dok treću karakteriziraju pojava intermitentnih simptoma s razdobljima bez bola tijekom dana ${ }^{4,5}$. Steele $^{17}$ navodi akronim SOCRATES kao jednostavnu i brzo pamtljivu mnemotehničku metodu. Svako početno slovo služi kao algoritam i podsjetnik pri uzimanju anamneze: S (engl. site-mjesto) - označava koja su bolna mjesta na oralnoj sluznici zahvaćena; O (engl. onset - početak) - postoji li postepena ili nagla pojava bola; C (engl. character - karakter bola) - kakav je karakter bola i mijenja li se; R (engl. radiation - širenje) - širi li se bol na drugi dio usta/lica ili je lokaliziran na određenom mjestu; A (engl. assoçiation -povezanost) - može li pacijent povezati neki drugi simptom s postojećim stanjem pečenja; T (engl. timing - vrijeme) - koliko su dugo simptomi prisutni; E (engl. 
exacerbating factors / pogoršavajući čimbenici) koji su čimbenici koji su povezani s pojačavanjem odnosno smanjenjem bola; S (engl. severity - težina) - označuje se pomoću vizualne analogne skale $(0-10)$ pomoću koje pacijent označava intenzitet bola. Lauria i suradnici ${ }^{18}$ smatraju da $\mathrm{u}$ boljem otkrivanju dijagnoze može pomoći bioptat uzet s područja prednje dvije trećine jezika. Biopsijom tkiva uzetog s mjesta gdje je izražen simptom pečenja uočena je smanjena gustoća živčanih vlakana s difuznim morfološkim promje-

Današnji terapijski pristup sindroma pekućih usta obuhvaća medikamentoznu terapiju, kao i bihevioralne i alternativne metode.

nama. Promjene u kvalitativnom sastavu sline također su zabilježene. U slini je utvrđena smanjena koncentracija magnezija i hondroitin sulfata te je povećana razina glandularnog kalikrenina, kalija, klora, kalcija, albumina, IgG, IgM, sekretornog IgA, lizosoma, natrija i amilaze ${ }^{12}$. Psihološka evaluacija može biti vrlo korisna jer oko 50 \% pacijenata sa SPU-om pokazuje različite znakove psiholoških poremećaja ${ }^{13}$.

\section{KLINIČKA SLIKA}

Nedostatak vidljivih lezija na oralnoj sluznici otežava jasnu dijagnozu sindroma. Najčešća je pojava senzoričkih simptoma poput pečenja, bola, hiperalgezije, dizestezije i subjektivne kserostomije $^{7}$. Pečenje predstavlja najčešći simptom kod pacijenata, a može se kvantificirati pomoću linearno analogne skale ${ }^{5,15}$. Bol se može javiti kao jedini simptom, no moguća je pojava drugih simptoma kao što je kserostomija i dizgeuzija ${ }^{1,4}$. Bol je najčešće spontan, a pacijenti ga opisuju kao gorenje, žarenje ili utrnulost ${ }^{4}$. Braud i suradnici ${ }^{9} \mathrm{u}$ istraživanju su naveli kako se u $77.8 \%$ slučajeva uz pečenje javlja i osjećaj suhih usta. Uz to je $u$ istraživanju zabilježena pojava taktilnog poremećaja u 66,7 \%, termalnog u 44.5 \% i okusnog u 38.9 \% slučajeva. Jedna trećina pacijenata početak bola povezuje s korištenjem lijekova ili prethodnim oralno-kirurškim zahvatom ${ }^{1,4}$. Nastanak mogu potaknuti stresan način života, umor, infekcije gornjeg respiratornog trakta, korištenje lije- kova (uključujući i antibiotsku terapiju), začinjena hrana i topli napitci te prethodni dentalni zahvati. Spontana remisija je rijetka, što potvrđuje istraživanje Sardella i suradnika ${ }^{19}$ koje govori o samo $3 \%$ spontane remisije zabilježene unutar pet godina od početka simptoma. Lokalizacija bola nije patognomoničan znak iako su jezik, nepce i donja usna najčešće zahvaćeni, a bukalna sluznica, dno usne šupljine, gornja usna te mandibularna alveolarna regija rjeđe navedeni kao bolna mjesta ${ }^{2,4}$.

\section{DIFERENCIJALNA DIJAGNOZA}

Osnovno pravilo postavljanja dijagnoze temelji se na isključenju svih potencijalnih organskih uzročnika. SPU na kraju možemo potvrditi jedino ako nakon opsežne dijagnostike koja obuhvaća analizu krvne slike, mjerenje razine folne kiseline, vitamina B 12, feritina, glukoze, tireotropina, hormona štitne žlijezde, luteinizirajućeg hormona, folikulostimulirajućeg hormona, anti SS-A protutijela, anti SS-B protutijela te reumatoidnog faktora i terapije navedenih stanja pacijent ne reagira smanjenjem simptoma ${ }^{20}$. Lokalna iritacija $u$ usnoj šupljini i prisutnost dentalnih materijala na kojima se razvija kontaktna osjetljivost može biti uzrokom pečenja usta ${ }^{21}$. Prilikom potvrđivanja konačne dijagnoze pozornost treba obratiti i na činjenicu da postoje još nekoliko kliničkih stanja koja mogu imati slične simptome. To je atipični facijalni bol, atipična odontalgija, temporo-mandibularni poremećaj i poremećaji mišića ${ }^{4}$. Ostali simptomi koji se spominju su upaljeno limfno tkivo unutar papila foliata, temporalni ili gigantski arteritis, mijeloblastični sindrom, refluksni ezofagitis i miofascijalni bol ${ }^{5}$. Sherman ${ }^{16}$ opisuje slučaj pacijentice koja je bolovala od celijakije s kliničkim simptomima pečenja jezika, prisutnima dvije godine. Simptomi bolesti u potpunosti su nestali deset tjedana nakon uvođenja bezglutenske prehrane.

\section{TERAPIJA}

Primarni terapijski pristup uključuje uklanjanje lokalnih iritacija i psihološku pomoć22,23. Čimbenici koji su se pokazali ublažavajućim u olakšavanju bola predstavljaju metode relaksacije te upotrebu hladnih napitaka i pastila ${ }^{1,15}$. Mnoge terapijske opcije usmjerene su na kontrolu i smanjenje neu- 
ropatskog bola ${ }^{13}$. Lijekovi u terapiji SPU-a mogu se podijeliti na one s topikalnom i sustavnom primjenom. Preporučeni topikalni lijekovi su benzidamin, klonazepam, kapsaicin i kortikosteroidi. Od sustavne primjene navode se klonazepam, gabapentin, lamotrigin, amisulpirid, trazodon, amilsupria, paroksetin, sertalin i alfalipoična kiselina ${ }^{12,20}$. Uloga lijekova kao što su benzodiazepini, antiepileptici i triciklički antidepresivi pomažu u kontroli simptoma, a ne u konačnom izlječenju ${ }^{23,24}$. Rezultati različitih studija govore o terapijskoj učinkovitosti prilikom upotrebe antikonvulziva klonazepama. Njegova učinkovitost zabilježena je u 70 \% slučajeva kod SPU-a. Uloga vrlo male doze ovog pripravka sastoji se u vezivanju za periferna i centralna receptorska mjesta te inhibiciju spontane centralne neuralne aktivnosti. Lijek posjeduje snažan učinak na moždani serotonergični sustav zbog veće mogućnosti vezanja na području centralnih receptora. Njegova upotreba pokazala se djelotvornom u mlađoj populaciji pacijenata, kao i kod pacijenata s višegodišnjim simptomima pečenja. Dugotrajnije ordiniranje ovog lijeka ne preporučuje se u starijoj populaci$j^{22}$. Također treba napomenuti i njegove moguće nuspojave kao što je pospanost, mučnina i vrtoglavica. Sustavni lijekovi koji se uz klonazepam mogu koristiti u terapiji SPU-a su kapsaicin, trazodon, amisulpirid, paroksetin i sertalin ${ }^{24}$. Također se u terapiji koristi alfa lipoična kiselina (ALK) koja sprječava oksidativno oštećenje živčanog sustava te je bitan koenzim koji sudjeluje u stvaranju energije $^{25}$. Upotreba ALK-a kroz mjesec dana dovodi do smanjenja simptoma. ALK ima određeni pozitivan učinak u terapiji SPU-a, no potrebna su dodatna istraživanja na većem broju ispitanika kako bi se potvrdila njena učinkovitost ${ }^{26-28}$. Obećavajuće rezultate u terapiji ima upotreba lasera. Laser ostvaruje analgetski, protuupalni i biostimulirajući učinak ${ }^{29,30}$. Terapija laserom niske snage $u$ istraživanju Spanemberga i suradnika ${ }^{29}$ pokazala je kako GaAlAs laser na postavkama od 830 nm, 100 mW i 5 J može imati značajan učinak na smanjenje bola. Učinak se ostvaruje inhibiranjem upalnih medijatora i povećanjem potencijala stanične membrane, čime se smanjuje brzina provođenja živčanog impulsa. Laserska terapija korištena tri puta tjedno dovela je u 67 \% slučaje- va do smanjenja bolnih simptoma i povećanja kvalitete života. Chow i suradnici ${ }^{31}$ navode kako laserska terapija svojim protuupalnim učinkom može povećati produkciju endogenog opioida i smanjiti sintezu ATP-a u aksonalnim mitohondrijima. Također se smatra kako njegovo djelovanje može dovesti do pojave dugotrajne nociceptorske promjene, a ponavljana upotreba može ubrzati reorganizaciju sinaptičkih veza koje sudjeluju u nastanku bola u središnjem živčanom sustavu. Jedan od novih terapijskih pristupa koji se također navodi obuhvaća i upotrebu pastila lokalnog anestetika bupivakaina koji bi mogao pridonijeti smanjenju simptoma bola. Rezultati Treldala i suradnika ${ }^{32}$ ukazuju na njegov učinak koji je statistički značajan, iako klinički minimalan. S obzirom na različite zaključke i rezultate novijih terapijskih pristupa u nastavku je prikazana tablica sa sažetim prikazom istraživanja.

\section{ZAKLJUČAK}

Iz dostupne literature možemo zaključiti da je terapijski pristup i dalje vrlo kompleksan. Zbog opsežnosti i mogućnosti pojave različitih simptoma koji ne moraju biti samo vezani za domenu dentalne medicine rješenje se i dalje nalazi u multidisciplinaranom pristupu koji je neophodan u postavljanju konačne dijagnoze. Osnovu za postavljenje dijagnoze trebalo bi potražiti u svim potencijalnim lokalnim i sustavnim uzrocima koji mogu biti povezani sa SPU-om. U recentnim znanstvenim radovima na temu terapijskog pristupa u rješavanju problematike vezane za SPU nađeni su različiti terapijski modeli. Za potvrđivanje učinkovitosti novijih metoda navedenih u tablici potrebne su studije koje će uključiti veći broj ispitanika te će biti provedene u dužem vremenskom razdoblju.

Izjava o sukobu interesa: Autorice izjavljuju da ne postoji sukob interesa.

\section{LITERATURA}

1. Klasser GD, Grushka M, Su N. Burning Mouth Syndrome. Oral Maxillofac Surg Clin North Am 2016;28:381-96.

2. Gurvits GE, Tan A. Burning mouth syndrome. World J Gastroenterol 2013;19:665-72.

3. Kamala KA, Sankethguddad S, Sujith SG, Tantradi P. Burning Mouth Syndrome. Indian J Palliat Care 2016; 22:74-9. 
4. Scala A, Checchi L, Montevecchi M, Marini I, Giamberardino MA. Crit Rev Oral Biol Med 2003;14:275-91.

5. Cibirka RM, Nelson SK, Lefebvre CA. Burning mouth syndrome: a review of etiologies. J Prosthet Dent 1997;8:93-7.

6. Rogulj AA, Richter I, Brailo V, Krstevski I, Boras VV. Katastrofiziranje u bolesnika sa sindromom pekućih usta. Acta Stomatol Croat 2014;48:109-15.

7. Penza P, Majorana A, Lombardi R, Camozzi F, Bonadeo S, Sapelli $P$, et al. "Burning tongue" and "burning tip": the diagnostic challenge of the burning mouth syndrome. Clin J Pain 2010;26:528-32.

8. Grushka M. Clinical features of burning mouth syndrome. Oral Surg Oral Med Oral Pathol 1987;63:30-6.

9. Braud A, Boucher Y. The relationship between the clinical features of idiopathic burning mouth syndrome and self-perceived quality of life. J Oral Sci 2016;58:475-81.

10. Davies, Grimes SR. Individual oral symptoms in burning mouth syndrome may be associated differentially with depression and anxiety. Acta Odontol Scand 2016;74: 155-60.

11. Suarez P, Clark GT. Burning mouth syndrome: an update on diagnosis and treatment methods. J Calif Dent Assoc 2006;34:611-22.

12. de Souza FT, Amaral TM, dos Santos TP, Abdo EN, Aguiar $\mathrm{MC}$, Teixeira AL, et al. Burning mouth syndrome: a therapeutic approach involving mechanical salivary stimulation. Headache 2012;52:1026-34.

13. Coculescu EC, Radu A, Coculescu BI. Burning mouth syndrome: a review on diagnosis and treatment. J Med Life 2014;7:512-5.

14. Lamey PJ, Lewis MA. Oral medicine in practice: burning mouth syndrome. Br Dent J 1989;167:197-200.

15. Adamo D, Celentano A, Ruoppo E, Cucciniello C, Pecoraro G, Aria M et al. The Relationship Between Sociodemographic Characteristics and Clinical Features in Burning Mouth Syndrome. Pain Med 2015;16:2171-9.

16. Sherman A, Zamulko A. Burning Tongue as Initial Presentation of Celiac Disease in an Elderly Woman: A Case Report. S D Med 2016;69:253-5.

17. Steele JC. The practical evaluation and management of patients with symptoms of a sore burning mouth. Clin Dermatol 2016;34:449-57.

18. Lauria G, Majorana A, Borgna M, Lombardi R, Penza P, Padovani $A$ et al. Trigeminal small-fiber sensory neuropathy causes burning mouth syndrome. Pain 2005;115: 332-7.

19. Sardella A, Lodi G, Demarosi F, Bez C, Cassano S, Carrassi A. Burning mouth syndrome: a retrospective study investigating spontaneous remission and response to treatments.Oral Dis 2006;12:152-5.

20. Silvestre FJ, Silvestre-Rangil J, López-Jornet P. Burning mouth syndrome: a review and update. Rev Neurol 2015;60:457-63.

21. Mock D, Chugh D. Burning Mouth Syndrome. Int J Oral Sci 2010;2:1-4.

22. Heckmann SM, Kirchner E, Grushka M, Wichmann MG, Hummel T. A double-blind study on clonazepam in patients with burning mouth syndrome. Laryngoscope 2012;122:813-6.

23. Sugaya NN, Sikva EFP, Kato IT, Prates R, Gallo C de B, Pellegrini VD. Low Intensity laser therapy in patients with burning mouth syndrome: a randomized, placebo-controlled study. Braz Oral Res 2016;10:108.

24. Jurisic Kvesic A, Zavoreo I, Basic Kes V, Vucicevic Boras V, Ciliga D, Gabric D et al. The effectiveness of acupuncture versus clonazepam in patients with burning mouth syndrome. Acupunct Med 2015;33:289-92.

25. Palacios-Sánchez B, Moreno-López L-A, Cerero-Lapiedra R, Llamas-Martínez S, Esparza-Gómez G. Alpha lipoic acid efficacy in burning mouth syndrome. A controlled clinical trial. Med Oral Patol Oral Cir Bucal. 2015;20:435-440.

26. Carbone M, Pentenero M, Carrozzo M, Ippolito A, Gandolfo S. Lack of efficacy of alpha-lipoic acid in burning mouth syndrome: A double-blind, randomized, placebocontrolled study. Eur J Pain 2009;13:492-6.

27. Cavalcanti DR, Da Silveira FRX. Alpha lipoic acid in burning mouth syndrome - a randomized double-blind placebo-controlled trial. J Oral Pathol Med 2009;38:254-61.

28. Femiano F, Gombos F, Scully C. Burning mouth syndrome: the efficacy of lipoic acid on subgroups. J Eur Acad Dermatology Venereol 2004;18:676-678.

29. Spanemberg JC, Lopez Lopez J, de Figueiredo MAZ, Cherubini K, Salum FG. Efficacy of low-level laser therapy for the treatment of burning mouth syndrome: a randomized, controlled trial. J Biomed Opt 2015;20:98001.

30. Arduino PG, Cafaro A, Garrone M, Gambino A, Cabras $\mathrm{M}$, Romagnoli $\mathrm{E}$ et al. A randomized pilot study to assess the safety and the value of low-level laser therapy versus clonazepam in patients with burning mouth syndrome. Lasers Med Sci 2016;31:811-6.

31. Chow RT, Heller GZ, Barnsley L. The effect of $300 \mathrm{~mW}, 830$ $\mathrm{nm}$ laser on chronic neck pain: A double-blind, randomized, placebo-controlled study. Pain 2006;124:201-10.

32. Treldal C, Jacobsen CB, Mogensen S, Rasmussen $M$, Jacobsen J, Petersen J et al. Effect of a local anesthetic lozenge in relief of symptoms in burning mouth syndrome. Oral Dis 2016;22:123-31.

33. Varoni EM, Lo Faro AF, Student P, Lodi G, Carrassi A, Iriti $\mathrm{M}$ et al. Melatonin Treatment in Patients with Burning Mouth Syndrome: A Triple-Blind, Placebo-Controlled, Crossover Randomized Clinical Trial. J Oral Facial Pain Headache 2018;178:178-88.

34. Barbosa NG, Gonzaga AKG, de Sena Fernandes LL, da Fonseca AG, Queiroz SIML, Lemos TMAM et al. Evaluation of laser therapy and alpha-lipoic acid for the treatment of burning mouth syndrome: a randomized clinical trial. Lasers Med Sci 2018; 33:1255-1262.

35. Jørgensen MR, Pedersen AML. Analgesic effect of topical oral capsaicin gel in burning mouth syndrome. Acta Odontolog Scand 2017;75:130-6.

36. Valenzuela S, Lopez-Jornet P. Effects of low-level laser therapy on burning mouth syndrome. J Oral Rehabil 2017;44:125-32.

37. Sugaya NN, Patr F, Kato IT, Prates R, Gallo B, Pellegrini VD. Low Intensity laser therapy in patients with burning mouth syndrome a randomized, placebo-controlled study. Braz Oral Res 2016;30:1-9.

38. Franco FR, Castro LA, Borsatto MC, Silveira EA, RibeiroRotta RF. Combined Acupuncture and Auriculotherapy in Burning Mouth Syndrome Treatment: A Preliminary Single-Arm Clinical Trial. J Altern Complement Med 2017; 23:126-34.

39. Shinozaki T, Imamura $Y$, Kohashi R, Dezawa K, Nakaya $Y$, Sato $Y$ et al. Spatial and Temporal Brain Responses to 
Noxious Heat Thermal Stimuli in Burning Mouth Syndrome. J Dent Res 2016;95:1138-46.

40. Valenzuela S, Pons-Fuster A, López-Jornet P. Effect of a $2 \%$ topical chamomile application for treating burning mouth syndrome: a controlled clinical trial. J Oral Pathol Med 2016;45:528-33.

41. Umezaki Y, Badran BW, Devries WH, Moss J, Gonzales T, George MS. The Efficacy of Daily Prefrontal Repetitive Transcranial Magnetic Stimulation (rTMS) for Burning Mouth Syndrome (BMS): A Randomized Controlled Single-blind Study. Brain Stimul 2016;9:234-42.

42. dos Santos L de FC, de Andrade SC, Nogueira GEC, Leão JC, de Freitas PM. Phototherapy on the Treatment of Burning Mouth Syndrome: A Prospective Analysis of 20 Cases. Photochem Photobiol 2015;91:1231-6.
43. Palacios-Sanchez B, Moreno-Lopez L, Cerero-Lapiedra R, Llamas-Martinez S, Esparza-Gomez G. Alpha lipoic acid efficacy in burning mouth syndrome. A controlled clinical trial. Med Oral Patol Oral Cir Bucal 2015;20:e43540.

44. de Castro LA, Ribeiro-Rotta RF. The effect of clonazepam mouthwash on the symptomatology of burning mouth syndrome: an open pilot study. Pain Med 2014;15:2164-5.

45. Cano-Carrillo P, Pons-Fuster A, López-Jornet P. Efficacy of lycopene-enriched virgin olive oil for treating burning mouth syndrome: a double-blind randomised. J Oral Rehabil 2014;41:296-305.

46. Silva LA, Siqueira JT, Teixeira MJ, Siqueira SR. The role of xerostomia in burning mouth syndrome: a case-control study. Arq Neuropsiquiatr 2014;72:91-8. 